
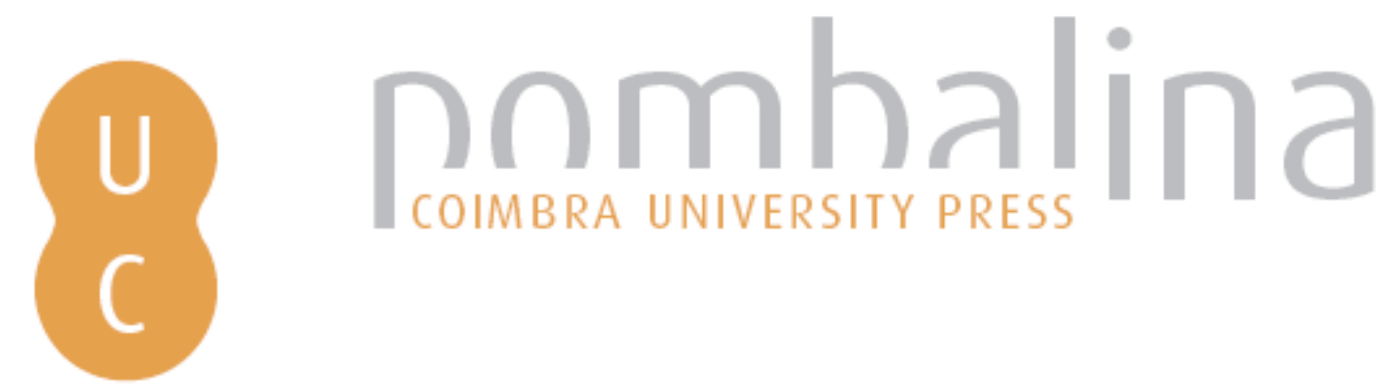

\title{
A propaganda nas ditaduras de Sidónio Pais e de Salazar: Afonso Costa como inimigo político, contrapropaganda e perseguição política
}
Autor(es):
Sousa, Jorge Pais de
Publicado por: Imprensa da Universidade de Coimbra
URL
persistente:
URI:http://hdl.handle.net/10316.2/38997
DOI:
DOI:http://dx.doi.org/10.14195/978-989-26-1064-1_3
Accessed : $\quad$ 26-Apr-2023 11:41:05

A navegação consulta e descarregamento dos títulos inseridos nas Bibliotecas Digitais UC Digitalis, UC Pombalina e UC Impactum, pressupõem a aceitação plena e sem reservas dos Termos e Condições de Uso destas Bibliotecas Digitais, disponíveis em https://digitalis.uc.pt/pt-pt/termos.

Conforme exposto nos referidos Termos e Condições de Uso, o descarregamento de títulos de acesso restrito requer uma licença válida de autorização devendo o utilizador aceder ao(s) documento(s) a partir de um endereço de IP da instituição detentora da supramencionada licença.

Ao utilizador é apenas permitido o descarregamento para uso pessoal, pelo que o emprego do(s) título(s) descarregado(s) para outro fim, designadamente comercial, carece de autorização do respetivo autor ou editor da obra.

Na medida em que todas as obras da UC Digitalis se encontram protegidas pelo Código do Direito de Autor e Direitos Conexos e demais legislação aplicável, toda a cópia, parcial ou total, deste documento, nos casos em que é legalmente admitida, deverá conter ou fazer-se acompanhar por este aviso.

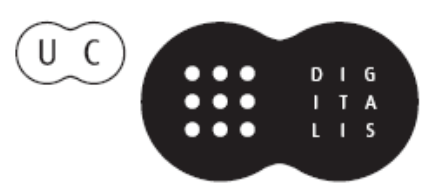


A L B ERTO PENA-RODR ÍGUEZ HELOISA PAULO

COOR D.

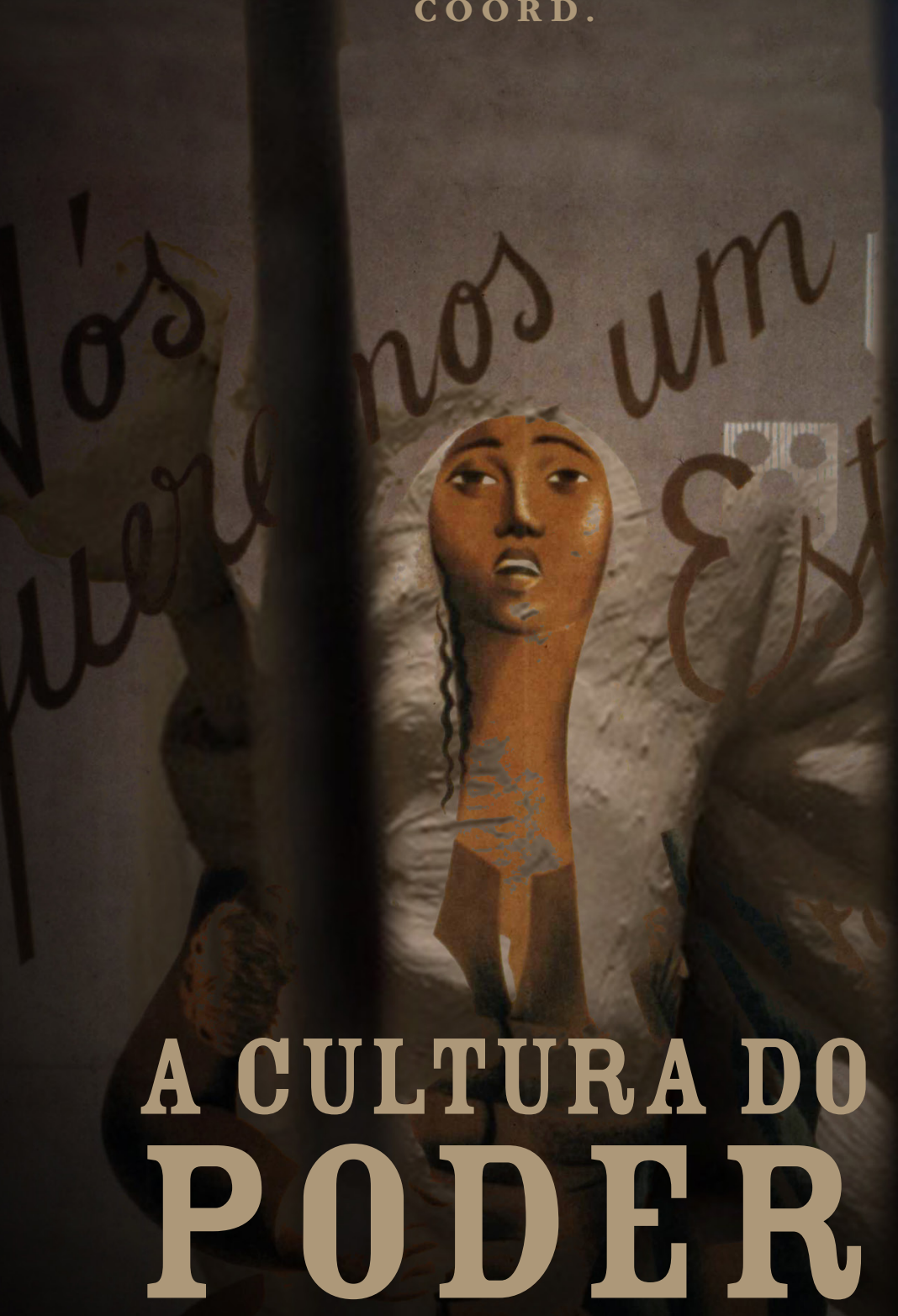

A PROPAGANDA INOS ESTADOS AUTORITÁRIOS 


\section{A PROPAGANDA NAS DITADURAS DESIDÓnIO PAIS E DE SALAZAR. \\ AFONSOCOSTA COMO INIMIGO POLítico, CONTRA P R O PA G A N D A \\ E PERSEGUIÇÃO POLÍTICA}

Jorge Pais de Sousa

[O] Secretariado não é um instrumento do Governo mas um instrumento de governo.

...Politicamente só existe o que o público sabe que existe

Salazar, Discursos

O objeto deste ensaio é analisar a emergência do fenómeno da propaganda de guerra em Portugal e o processo histórico da sua apropriação para fins exclusivamente políticos pelas ditaduras de Sidónio Pais e de Salazar.

Com efeito, a participação de Portugal na I Grande Guerra Mundial implicou a necessidade de organizar e constituir um aparelho de propaganda intervencionista, pelo ministro da Guerra Norton de Matos (julho de 1915 a dezembro de 1917). A "guerra de Gabinetes", como também ficou conhecida, é travada em todos os países beligerantes. E é a importância da consciência política em travar, na frente interna, a guerra da propaganda que faz da Grande Guerra 
o primeiro conflito "total" do século $\mathrm{XX}$, no sentido em que existe uma consciência, política e militar, de se travar, em paralelo, a guerra em duas frentes distintas: na frente "interna" uma guerra psicológica junto da opinião pública e publicada; e na frente externa uma guerra de trincheiras que obedece a uma tática desenvolvida pelo exército alemão.

É também no contexto da guerra interna, travada também pelos intelectuais, que o modernismo futurista se manifesta em Portugal. Primeiro, com a publicação dos dois números da revista "Orpheu" que vêm a público ao longo do primeiro semestre de 1915 e quase que coincidido com a ditadura do general Pimenta de Castro. E, num segundo momento, com a publicação de "Sphinx: Revista de Novos", cujos dois números são publicados durante o primeiro trimestre de 1917. E, no mês de novembro, é publicado o número único da revista "Portugal Futurista" que suscita a imediata apreensão pelas autoridades policiais.

Entretanto, o agravamento da crise económica e social e a mobilização que se segue, após a declaração de guerra da Alemanha a Portugal, a 9 de março de 1916, e o consequente desembarque de tropas portuguesas para combater na Flandres francesa a partir de janeiro de 1917, precipitam o golpe de Estado comandado, a 5 de dezembro de 1917, pelo militar e catedrático Sidónio Pais. É em ditadura que Sidónio Pais se apropria do aparelho militar de propaganda intervencionista e direciona-o para a construção do seu carisma político, ao mesmo tempo que nomeia Diretor-Geral Homem Cristo Filho para dirigir, em Paris, a DSIPRPPAA, a primeira estrutura governamental criada em Portugal vocacionada, especificamente, para a propaganda.

Sustentamos que, sem um estudo sistemático da participação portuguesa na I Guerra Mundial em matéria de propaganda, quer na frente externa quer na frente interna, bem como do comportamento político de Homem Cristo Filho e de António Ferro, não é 
possível perceber porque é que Salazar vai dar posse a este último, a 26 de outubro de 1933, como diretor do Secretariado de Propaganda Nacional (SPN).

A terminar analisamos, como exemplo, o processo de propaganda que conduz Salazar a escrever a Nota Oficiosa "I Duas Escolas Políticas", em que declara Afonso Costa como seu inimigo político a 17 de julho de 1934, e como, a partir de então, o SPN o trata como objeto de contrapropaganda e o Estado Novo o persegue politicamente até ao fim da sua vida.

\section{A intervenção de Portugal na I Guerra Mundial implicou a criação de um gabinete e de estruturas de propaganda no Ministério da Guerra. A afirmação do modernismo futurista na frente interna}

Portugal mobiliza e envia para combater em África, desde o verão de 1914 até 1919, ou seja, desde o início da eclosão até ao fim do primeiro conflito à escala mundial, cerca de 55 mil homens no teatro de guerra africano (34 600 das Forças Armadas metropolitanas e 19500 soldados indígenas). Este dispositivo militar é instalado no teatro de guerra africano nas colónias de Angola e Moçambique, uma vez que estes territórios faziam fronteira, respetivamente, a sul e a norte, com duas colónias alemãs, a Damaralândia e a África Oriental Alemã. Os graves confrontos militares fronteiriços começaram primeiro em Angola e, posteriormente, estenderam-se a Moçambique, tendo-se registado incidentes militares fronteiriços graves que levaram os sucessivos governos portugueses a procederem ao reforço da defesa militar das duas maiores e mais importantes colónias.

É no quadro militar da guerra em África que ocorre o Golpe das Espadas em Lisboa e tem início, a 25 de janeiro de 1915, a Ditadura do general Pimenta de Castro. Esta termina com a eclosão da violenta 
e sangrenta revolução constitucionalista de 14 de maio de 1915, que leva os democráticos a regressarem ao poder após a realização de eleições. Na sequência, o major Norton de Matos torna-se ministro da Guerra, durante o governo presidido por José de Castro. E detém esta pasta, ininterruptamente, entre 22 de julho de 1915 até ao $2 .^{\circ}$ governo da União Sagrada presidido por Afonso Costa, quando ocorre, a 5 de dezembro de 1917, o golpe de Estado de Sidónio Pais. Entretanto, a 9 de março de 1916 tem lugar a declaração de guerra da Alemanha a Portugal, em resultado da requisição dos navios alemães surtos em portos portugueses. Durante estes 17 meses de política intervencionista, coerente e sólida, foi possível preparar o Exército, designadamente através da organização das primeiras manobras militares no Polígono Militar de Tancos, para combater no exigente teatro de guerra europeu. Por isso, em fevereiro de 1917, o Corpo Expedicionário Português (CEP) é constituído por duas divisões que totalizam 55000 homens. E estas, por sua vez, formam um Corpo de Exército integrado no dispositivo militar britânico estacionado para combate na Flandres francesa. ${ }^{1}$

$\mathrm{Na}$ frente interna, e no quadro do que Emilio Gentile designou de "guerra dos intelectuais", em janeiro de 1915, é publicado o primeiro número da revista Orpheu. E entre janeiro e março de 1917 são publicados dois números de "Sphinx: Revista de Novos", onde colaboram entre outros os estudantes de Belas Artes, Carlos Ramos, Leitão de Barros e Cotinnelli Telmo. Em novembro de 1917 - mas logo apreendida pela polícia - sai a público a revista Portugal Futurista. Nesta se percebe a clara influência da estética da vanguarda futurista de Marinetti e também da filosofia do Super-homem de Nietzsche (1844-1900), para a chamada Geração de Orpheu, designadamente,

1 Sobre o número total dos efetivos portugueses combatentes em África e na Europa, cf. BARATA, Manuel Themudo; TEIXEIRA, Nuno Severiano - Nova História Militar de Portugal. vol. 4. Lisboa: Círculo de Leitores, 2003. ISBN 972-42-3209-3, pp. 25 e 27. 
no Ultimato do engenheiro Álvaro de Campos, o heterónimo futurista de Fernando Pessoa, e sobretudo no Ultimato Futurista às Gerações Portuguesas do Século XX de Almada Negreiros. Sublinhe-se, pois, que a publicação destas três revistas abre ou antecede, respetivamente, as ditaduras de Pimenta de Castro e de Sidónio Pais. ${ }^{2}$ Todavia, e comparando com os sequazes de Marinetti em Itália, em dois aspetos o comportamento político dos intelectuais futuristas portugueses se diferenciou historicamente. Primeiro, não são consequentes com a apologia guerrista e a sua esteticização e, por isso, não se mobilizaram como voluntários para combater na guerra de trincheiras. Segundo, e no pós-guerra, também não constituíram um Partido Futurista (PFI) para terem intervenção política no campo partidário como aconteceu em Itália. Porque muito cedo, como é sabido, os futuristas de Marinetti vão associar-se aos "Fascios di Combattimento" de Mussolini. Aliás, os "Fascios" futuristas constituíam as células estruturantes da organização do Partido Futurista Italiano dirigido por Marinetti. E não é por acaso que está em aberto o debate na historiografia italiana para saber em que medida é que a linguagem estética do fascismo não resultou da apropriação das propostas, estéticas e políticas, preconizadas por Fillipo Marinetti nos seus escritos teóricos e na sua intervenção política. ${ }^{3}$

$O$ que não significa que os membros da denominada Geração de Orpheu, individualmente considerados, não venham a ter intervenção política. Fernando Pessoa, por exemplo, vai militar no Núcleo de Acção Nacional e, nessa qualidade, escreve e publica o jornal "Acção" órgão de imprensa desta organização sidonista e nacionalis-

\footnotetext{
2 Procedendo a uma análise comparada, dedicámos à relação entre os futuristas e a república o seguinte ensaio: SOUSA, Jorge Pais de. "Os Futuristas e a República", in MARNOTO, Rita (Coord.) - Leonardo: Causa Pública. Coimbra: Imprensa da Universidade; Instituto de Estudos Italianos, 6, 2011. ISBN 978-989-26-0130-4, pp. 187-240.

3 Cf. SOUSA, Jorge Pais de. "Os Futuristas e a República", in: MARNOTO, Rita (Coord.). Leonardo: Causa Pública. pp. 188-192.
} 
ta. É nele que publica pela primeira vez, a 27 de fevereiro de 1920 , a célebre ode sidonista À Memória do Presidente-Rei Sidónio Pais. Recorde-se que o poeta órfico escrevera antes, entre os dias 5 e 8 de dezembro de 1917, ou seja os dias do golpe de Estado comandado pelo militar e catedrático Sidónio Pais, vários poemas contra Afonso Costa e a concepção democrática de República que este, em termos políticos, defendeu e protagonizou. Foi neste sentido que analisámos, por exemplo, o conteúdo ideológico e paradigmático dos seguintes poemas pessoanos: Marcha Fúnebre [RPRIP - República Portuguesa Requiescet in Pace] e Afonso Costa. ${ }^{4}$ Todavia, e antes, entre os meses de fevereiro e março de 1917, são publicados, também em Lisboa, dois números da revista Sphinx: Revista de Novos. Uma revista estudantil que, quanto a nós, é muito pobre ao nível da cultura literária e gráfica, e neste sentido tem muito pouco de "novo". $\mathrm{Na}$ verdade, em nada cumpre os preceitos do Manifesto tecnico della literatura futurista, publicado por Marinetti em 1912.5 O texto que abre o primeiro número da revista é da autoria de Celestino Soares, então aluno da Faculdade de Letras de Lisboa, e pretende situar a publicação no panorama intelectual português, mas o que é sintomático em termos intelectuais é que se refere a Nietzsche sem nunca identificar o filósofo de Rocken:

A nossa revista é, pois, mais uma das muitas tentativas para a Emancipação do Espírito que a Civilização e as Escolas transformaram, por forma a fazer do homem de hoje - uma "criatura anti-humana, sem beleza, sem força, sem liberdade, sem riso, sem

\footnotetext{
${ }^{4}$ Sobre a militância sidonista de Fernando Pessoa e a sidonofilia de Salazar patente na trasladação da urna do "Presidente-Rei" para o Panteão Nacional no dia 5 de Dezembro de 1996, em plenas comemorações pelo Estado Novo do $40 .^{\circ}$ Aniversário da Revolução Nacional, cf. Id., o. c., pp. 207-234.

5 Cf. MARINETTI, Fillipo. Teoria e Invenzione Futurista. 6. ${ }^{a}$ ed. Milão: Arnaldo Mondadori, 2005. ISBN 88-04-22037-6, pp.46-54.
} 
sentimento, e trazendo em si um espírito que é passivo como um escravo ou impudente como um histrião', de tal modo que 'todos, intelectualmente, são carneiros trilhando o mesmo trilho, balando o mesmo balido, com o focinho pendido para a poeira onde pisam em fila as pegadas já pisadas." 6

É só no segundo e derradeiro número de "Sphinx: Revista de Novos" que é publicada a ficha técnica da publicação. Esta informa que o seu secretário e editor é Luís de Almeida Nogueira, então estudante de Medicina. Esta revista de estudantes do ensino superior de Lisboa surge dividida em Literária e Artística. Laura de Almeida Nogueira e Celestino Soares, este é aluno da Faculdade de Letras, são os diretores literários. José Leitão de Barros e Cottinelli Telmo, ambos alunos da Escola de Belas Artes, asseguram a direção artística. No grupo de fundadores surgem primeiramente nomeadas Teresa Leitão de Barros e Laura de Almeida Nogueira. Os nomes das duas mulheres são os únicos que não surgem associados à frequência de uma escola de ensino lisboeta, pelo que devemos deduzir que não faziam estudos superiores. Carlos Chambers Ramos, Cottinelli Telmo e José Leitão de Barros estudam arquitetura na Escola de Belas Artes. Luís de Almeida Nogueira, Luís Reis Santos e Luís Simões Raposo são alunos na Faculdade de Medicina. José Mercier Santos é aluno do Instituto Superior Técnico. ${ }^{7}$

É durante a ditadura de Sidónio Pais que vários destes estudantes participam na fundação da Sociedade Lusitânia Films, no ano de 1918, com vista a controlar os setores da produção, distribuição e exibição de filmes em Portugal. A sociedade é gerida por Celestino Soares, o diretor artístico é Luís Reis Santos, sendo os restantes

6 SOARES, Celestino. "É muito difícil traçar um plano...", in: Sphinx: Revista de Novos. Lisboa, [fev. 1917], n. ${ }^{\circ} 1$, p. 1.

7 Cf. Sphinx: Revista de Novos. Lisboa, março de 1917, n. ${ }^{\circ}$ 2, p. 23. 
sócios Carlos Ramos, Cottinelli Telmo, António Mexia Salema, João Contreiras Queriol, e Luís Roquete. O sócio que financia a Sociedade Lusitânia é Júlio Fernandes Potes, estudante liceal finalista e filho de abastados lavradores. ${ }^{8}$ E nem por acaso, a Sociedade Lusitânia Films vai começar por produzir cinco documentários de "atualidades", onde Sidónio Pais é o protagonista principal, a saber: Tourada de Gala no Campo Pequeno; O Dr. Sidónio Pais no sul do país; Manobras no campo entricheirado de Lisboa; Parada Militar; e 5 de Outubro.?

Ao mesmo tempo, e no campo universitário, a "guerra dos intelectuais" nacionalistas tem o seu auge na publicação, entre 1916 e 1918, dos principais trabalhos académicos de Salazar e que lhe permitem ascender à cátedra de Economia Política e Finanças. Em Questão Cerealífera: O Trigo e O Ágio de Ouro: Sua Natureza e suas Causas, dois estudos publicados em 1916, sob o título conjunto de Estudos de Economia Nacional. E no artigo Alguns Aspectos da Crise de Subsistências (1918), Salazar propõe a criação de um "ditador de víveres." 10 para a resolução deste problema. Ou seja, percebemos que existe um objeto de estudo comum na preparação dos trabalhos universitários de Salazar e que é a análise e as consequências da I Guerra Mundial na economia e nas finanças portuguesas. Em suma, Salazar especializou-se em economia de guerra.

Ainda na frente interna, mas na perspetiva governamental da "Guerra de Gabinetes" e no esforço de promoção de uma política intervencionista existe, sobretudo no major Norton de Matos, a consciência militar de se estar perante a primeira guerra "total". E para a estruturação dessa consciência política muito contribuiu a recepção,

8 Cf. COUTINHO, Bárbara dos Santos. Carlos Ramos (1897-1969): Obra, pensamento e acção. A procura do compromisso entre o Modernismo e a Tradição, vol. I, p.. 28.

9 Cf. Id., Ibidem.

10 Cf. SOUSA, Jorge Pais de. O Fascismo Catedrático de Salazar: Das Origens na I Guerra Mundial à Intervenção Militar na Guerra Civil de Espanha 1914-1939. Coimbra: Imprensa da Universidade, 2011. ISBN 978-989-26-0020-8, pp. 276-282. 
em Portugal, da obra de Gustave Le Bon (1841-1931). Médico de formação, Le Bon fundara a chamada psicologia social no final do século XIX ao publicar livros como Lois Psychologiques de L'Évolution des Peuples (1894) e, sobretudo, o famoso Psychologie des Foules (1895). À medida que o conflito se desenrola este torna-se para este médico uma espécie de laboratório vivo e, neste sentido, objecto de estudo privilegiado no quadro mais geral das suas investigações. As traduções dos livros que escreveu, em pleno conflito, são publicadas em Portugal com uma enorme rapidez. Assim, e publicados no ano de 1916, temos os dois livros: Ensinamentos Psicológicos da Guerra Europeia; e As Primeiras Consequências da Guerra: Transformação Mental dos Povos.

A consciência política em conhecer o esforço de guerra levado a cabo pelos países Aliados levara a que O Espelho: Jornal Ilustrado (1914-1918), de origem brasileira, e com publicação em Londres, ou seja, um jornal de tipo magazine muito cuidado, em matéria de qualidade gráfica dos textos, fotografia e ilustração, circulasse e fosse lido em Portugal.

Em Paris, porém, desde a primeira hora em que o conflito estalou que João Chagas desenvolveu um esforço diplomático de índole intervencionista, como o provou um estudo recente efetuado com base na análise da correspondência diplomática que estabeleceu com o Ministério dos Negócios Estrangeiros em Lisboa. Assim, e logo que este objectivo político-diplomático foi concretizado, e para apoiar em termos de propaganda o esforço de guerra realizado pelo Corpo Expedicionário Português (CEP), com o primeiro desembarque na Flandres acontecido em Janeiro de 1917, passou a ser publicada na capital francesa Portugal na Guerra: Revista Quinzenal Ilustrada, ${ }^{11}$ entre Junho e Novembro de 1917, com direção de Augusto Pina.

11 Ver: http://hemerotecadigital.cm.lisboa.pt/Periodicos/PortugalnaGuerra/ PortugalnaGuerra.htm 
Os sete números desta revista são vendidos e divulgados em países como a França, Portugal e Brasil. A ficha técnica da publicação informa que ela dispunha de um "serviço fotográfico especial junto das tropas portuguesas em França a cargo de Arnaldo Garcez". Trata-se de um revista com uma boa qualidade gráfica e o conteúdo das suas reportagens denota o carácter oficial da publicação. É neste sentido que, por exemplo, se compreende que os dois últimos números publicados, em Outubro e Novembro de 1917, apresentem uma cobertura, jornalística e fotográfica, da visita do presidente da República Bernardino Machado e do presidente do Ministério Afonso Costa, às tropas portuguesas estacionadas no "front" francês. Significativo também, mas agora em termos de política de contramobilização sidonista, é o facto desta revista Portugal na Guerra ter sido suspensa e deixado de ser publicada após o golpe de Estado de 5 de dezembro de 1917.12

No que respeita à estrutura de apoio militar e de propaganda que o major Norton de Matos organiza no Ministério da Guerra, este gabinete tinha a chefiá-lo o capitão Almeida Santos e contava: no domínio técnico-militar, com a colaboração dos capitães António de Almeida, Florentino Martins e Salvador José da Costa, e do tenente José Fernandes; enquanto, no campo da propaganda, tinha como colaboradores o pintor Sousa Lopes e o fotógrafo Arnaldo Garcez. O livro de Norton de Matos Memórias ao Longo de Uma Vida, constitui uma fonte decisiva para se perceber e reconstituir toda a sua ação política à frente do Ministério da Guerra entre julho de 1915 e dezembro de 1917.

Inseriu-se também no campo da propaganda do esforço de guerra, o convite formulado por Norton de Matos a Jaime Cortesão

12 Cf. SOUSA, Jorge Pais de. O Fascismo Catedrático de Salazar: Das Origens na I Guerra Mundial à Intervenção Militar na Guerra Civil de Espanha 1914-1939, pp. 32-34. 
para escrever uma nova Cartilha do Povo. Esta é publicada para esclarecer os soldados e a população em geral, como escreveu o seu autor, Jaime Cortesão, um destacado intelectual do movimento da Renascença Portuguesa, então capitão médico voluntário no "Front" francês e também deputado pelo PRP/Partido Democrático. Trata-se de um texto escrito, num estilo de perguntas e respostas, para apelar ao sentimento pátrio do soldado combatente. A pensar por certo que, à boa maneira republicana, esta cartilha devia ser lida também em voz alta e suscitar a discussão e o debate entre os soldados mobilizados para a frente de combate, uma vez que na sua maioria tratavam-se de combatentes analfabetos ou com enormes deficites de instrução. É neste quadro da condução da guerra entre gabinetes que a nova Cartilha do Povo foi editada no Porto, pela Renascença Portuguesa, e atingiu o número inusitado, para a época, de 100 mil exemplares impressos. E a verdade é que, não obstante esta tiragem elevadíssima, não se encontra hoje esta publicação nas principais bibliotecas públicas.

Por outro lado, a moderna condução política da guerra de Gabinetes levou a que o ministro da Guerra Norton de Matos criasse dois organismos oficiais dentro do Exército para divulgarem, amplamente, o esforço de guerra português, pelo recurso à imagem fixa e à imagem em movimento, referimo-nos ao Serviço Fotográfico do CEP e à Secção Cinematográfica do Exército.

No campo da fotografia, António Pedro Vicente teve a oportunidade de estudar que a I Guerra Mundial foi o primeiro conflito "fotografado a partir de dentro", na medida em que os fotógrafos, na maior parte dos casos figuras anónimas, registavam imagens oficiais sobre o duro quotidiano dos soldados nas trincheiras, as casas destruídas, as crateras abertas pelas bombas, sendo certo que a morte e o ferimento brutal que originam a mutilação dos corpos dos combatentes - tendo em linha de conta os ensinamentos da 
guerra psicológica de Gustave Le Bon - não eram mostrados para evitar a desmoralização dos soldados e da opinião pública.

Apesar destas limitações na cobertura fotográfica, a câmara oficial de Arnaldo Garcez realizou, num primeiro momento, a reportagem da preparação militar a que foi sujeita a Divisão de Instrução em Tancos, desde a sua concentração, instrução, até ao embarque para a Flandres. Num segundo momento, foi-lhe conferido o posto de alferes equiparado para seguir para França e produzir na frente de combate imagens relativas a diferentes aspectos da campanha militar realizada pelos combatentes portugueses em solo francês. Em França, fotografou os exercícios militares, os batalhões a caminho da frente de combate, o quotidiano dos "serranos" nas trincheiras, os encontros entre estados-maiores, as visitas ministeriais e presidenciais, até aos desfiles do exército português nos Campos Elísios, durante o 14 de Julho, etc. Em todas as situações, Arnaldo Garcez desenvolveu o seu trabalho de recolha de imagens sempre na qualidade de fotógrafo, oficial e exclusivo, do CEP, servindo-se da objectiva da sua câmara para transmitir, sobretudo, imagens sobre a realidade e a sofisticação técnica atingida por este fenómeno marcial.

O cinema foi também um sector da propaganda onde a temática da participação portuguesa na I Guerra Mundial ficou amplamente registada. A análise da obra Prontuário do Cinema Português, de José de Mattos Cruz, comprova esta afirmação. Por exemplo em 1914, ou seja, no primeiro ano do conflito, foram produzidos em Portugal um total de 35 filmes, sendo que 14 de entre estes tratam temáticas relativas à guerra. O que é bastante significativo, sobretudo, se tivermos presente que o conflito se iniciara no mês de Agosto. Assim, nos 14 filmes considerados, surgem imagens relativas à organização de paradas e de exercícios militares, embarques de tropas expedicionárias para combater em África, manifestações de apoio às nações aliadas, etc. Não podemos esquecer, ainda, que os 3 filmes rodados sobre o 5 de Outubro incluem também imagens 
com desfiles militares. O que significa também que, em apenas 4 meses de conflito, a temática da guerra alastrara e passa a ser objecto de actualidade noticiosa e de cobertura cinematográfica. Enquanto no ano de 1915 se regista uma quebra comparativa, quer em termos de número total de filmes produzidos, apenas 27 , quer quanto aos filmes que abordam a temática da guerra, apenas 7 . É possível aventar que o facto da ditadura pimentista ter vigorado durante cinco meses ajude a explicar esta quebra geral na produção cinematográfica, tal como o acentuar das dificuldades sentidas com o alongar e o agravamento do conflito. No entanto, e já coincidindo com o desenvolvimento da política intervencionista que Norton de Matos desenvolve no Ministério da Guerra, constata-se que no ano de 1916 a produção geral de filmes cresceu para 74 películas e, de entre elas, 19 abordam a temática da guerra. A explicar o aumento desta produção cinematográfica está, sem dúvida, o facto de Norton de Matos ter criado neste ano de 1917 a Secção Cinematográfica do Exército. Um organismo que produziu oito (8) dos filmes que tratam esta matéria, ou seja, metade dos filmes que se produziram em 1917 sobre a guerra. Atentemos nos títulos das películas produzidas e na preocupação em divulgar os aspectos mais amplos e diferenciados da política de esforço de guerra, a saber: "Entrega da Bandeira de Lisboa ao Cruzador Vasco da Gama"; "Escola de Aviação em Vila Nova da Rainha"; "Escola de Oficiais Milicianos em Queluz"; "Lançamento da Canhoneira Bengo"; "Participação de Portugal na Guerra; Provas Finais dos Alunos da Escola de Guerra"; "Transporte de Tropas para França; e "Tropas Portuguesa no Front". ${ }^{13}$

13 Cf. SOUSA, Jorge Pais de. O Fascismo Catedrático de Salazar: Das Origens na I Guerra Mundial à Intervenção Militar na Guerra Civil de Espanha 1914-1939, pp. 94-98. 


\section{A ditadura de Sidónio Pais apropria-se das estruturas militares e cria a primeira Direção-Geral de propaganda}

Há um aspecto importante a destacar em resultado da instauração da ditadura de Sidónio Pais, é que esta última assinala uma ruptura com a anterior dimensão estritamente civilista de sete anos de exercício da magistratura da presidência da República. Até então o país conhecera três presidentes da República civis, Teófilo de Braga, Manuel de Arriaga e Bernardino Machado. Em tempo de guerra, a condição dupla de Sidónio Pais, como professor catedrático de Cálculo Diferencial e Integral da Faculdade de Matemática da Universidade de Coimbra e, simultaneamente, de Major de Artilharia, leva a que este opte por aparecer em público envergando o uniforme de militar. A opção pela sua condição castrense associada ao estatuto de Presidente da República, que por inerência do cargo comanda as Forças Armadas, permite-lhe também tirar partido dos instrumentos de propaganda de guerra e colocá-los ao serviço da construção do seu carisma pessoal e da sua imagem política, externa e internamente. Sidónio Pais abriu, portanto, um precedente castrense na história da mais alta magistratura republicana durante a chamada "República Nova”, o qual será depois retomado e assumido, mais tarde, durante todo o Estado Novo. Ao suspender a Constituição de 1911 e dissolver o Congresso, exilar o presidente da República Bernardino Machado e mandar prender o presidente do Ministério Afonso Costa, Sidónio Pais envereda por uma via de ditadura presidencialista de governo, segunda a qual o presidente da República concentra e acumula com as funções de presidente do Governo. Porventura, a rotura completa com a República parlamentar fundada a 5 de Outubro de 1910 ficou bem visível na forma como Sidónio Pais mandou prender e manteve detido Afonso Costa. É no seu regresso da conferência dos governos aliados, realizada em Paris, que é "preso no Porto, transportado para o forte da Trafaria, depois para Elvas onde, durante três meses, 
ficou encerrado." 14 Acontece que o presidente do Governo esteve preso durante este tempo sem nunca ter sido ouvido, acusado e julgado. É o arbítrio completo. E quando Afonso Costa é libertado no dia 30 de março de 1918, curiosamente, nesse dia é publicado o decreto eleitoral sidonista que legisla sobre matéria constitucional. Entre outras medidas, decreta-se a representação profissional para parte do Senado, mas veja-se a rotura com a tradição parlamentar - inscrita no preâmbulo do diploma - e que remonta à instauração do liberalismo em Portugal:

Em verdade, a experiência demonstra que um dos maiores vícios do parlamentarismo, entre nós, é a confusão vulgaríssima entre os dois poderes Legislativo e Executivo. Fazer que o primeiro gere o segundo é envolver este na dependência da paternidade política. Para haver independência mútua é preciso que ambos os poderes tenham origem igual e sejam, assim, igualmente fortes, que ambos desempenhem a sua missão e vão a seu fim sem se dominarem ou confundirem.

Por isso o governo não só preferiu adoptar a eleição presidencial directa, mas arroga ao Executivo algumas atribuições imprescindíveis ao exercício de tal poder, que não se encontravam claramente expressas na Constituição de 1911, do que muito desprestígio adveio ao nosso sistema político. ${ }^{15}$

Sabemos que a redação da lei eleitoral sidonista é feita e supervisionada pelo ministro da Justiça Martinho Nobre de Melo (1891-1985). Na verdade, é este professor da Faculdade de Direito da Universidade de Lisboa, onde era colega de Afonso Costa e seu antigo aluno em Coimbra, que convida os integralistas Hipólito

\footnotetext{
14 MARQUES, A. H. de Oliveira. Afonso Costa. 2. ${ }^{a}$ ed. Lisboa: Arcádia, 1975, p. 41.

15 Diário de Governo, I Série, Decreto 3 997, n. ${ }^{\circ}$ 64, pp. 292-293.
} 
Raposo e António Sardinha para elaborarem o diploma que seria, no seu entendimento e segundo as suas palavras: "uma lei, espécie de Constituição provisória no quadro da qual as instituições se movimentassem..." 16 Oito anos mais tarde, após o golpe de Estado do 28 de maio de 1926 que instaura a Ditadura Militar, é o mesmo Martinho Nobre de Melo que, agora na condição de ministro dos Negócios Estrangeiros, exonera Afonso Costa das funções de representante de Portugal na Sociedade das Nações (SN). E porque é que Sidónio convidara Martinho Nobre de Melo para ser seu ministro da Justiça? Porque procurava "um moço, com ideias novas, que pudesse harmonizar-se com os tempos novos."17 Não é, pois, por acaso que o adjetivo "novo" qualifica a República e a "situação" política ditatorial imposta por Sidónio Pais ao país e assume um significado político, jurídico e estético, que também lhe advém da emergência do contexto belicoso subjacente à linguagem da vanguarda futurista. Este plasmara-se, em Itália, nos trabalhos e no pensamento jurídico-político sobre o Stato Nuovo do catedrático de Direito Alfredo Rocco (1875-1935), ou seja, um dos mais importantes intelectuais do fascismo corporativista e que, entre 1925 e 1932, se torna ministro da Justiça de Mussolini.

Para reforçar, no entanto, a construção do seu carisma e da sua imagem política, o "novo" ditador Sidónio Pais faz da cidade de Lisboa um palco de eleição, onde as paradas e os desfiles militares se tornam numa constante durante a sua presidência. Por exemplo, no dia 10 de dezembro de 1917, assinalou e comemorou o êxito do seu golpe de Estado, com uma parada militar que desfilou pela Rua Joaquim António de Aguiar, Avenida da Liberdade, até ao obelisco dos Restauradores. Parada em que Sidónio surge em público

16 Entrevista com um Ministro de Sidónio: Nobre de Melo, em ANTUNES, José Freire. A Cadeira de Sidónio: Ou a Memória do Presidencialismo. Mem-Martins: Europa-América, 1981, p, 173.

17 Id., o. c., p. 170. 
montando a cavalo e envergando o uniforme militar - o mesmo que era utilizado pelas tropas expedicionárias - ostentando logo a graduação de general de cinco estrelas, própria do comandante em chefe das Forças Armadas. Este cuidado com a encenação militar foi ao ponto de ser, por diversas vezes, fotografado e filmado em pose equestre a montar um elegante cavalo Alter Real que lhe fora oferecido.

Em termos de psicologia das multidões, a utilização do uniforme pelo presidente da República permite a Sidónio Pais estabelecer uma identificação e um contacto de proximidade e, neste sentido, apresentar-se como mais um soldado/cidadão que comunga com o "povo" a conjuntura crítica de guerra, de fome e de doença - tifo e pneumónica -, agravadas pelo contexto de uma crise económica e social impiedosa que acompanhou o final do conflito e a governação sidonista durante o ano de 1918.

No que respeita à instrumentalização dos organismos oficiais de propaganda ao serviço da projecção da imagem política interna do "Presidente-Rei" é de sublinhar que Sidónio Pais procedeu à fusão das duas estruturas criadas pelo ministro da Guerra Norton de Matos. E, deste modo, a 8 de Maio de 1918, o Diário do Governo publica o decreto que cria e regulamenta a "nova" Secção Fotográfica e Cinematográfica do Exército. Repare-se, no entanto, na amplitude do objecto que é atribuído a este organismo militar vocacionado, supostamente, para fazer a propaganda de Portugal:

Registar para serem utilizados na projecção fixa e animada, todos os assuntos relativos à educação e preparação do exército, na paz e na guerra, e tudo quanto possa aproveitar à instrução pública, à educação física e à propaganda de Portugal no estrangeiro, quer pela cinematografia de assuntos panorâmicos e regionais dos mais interessantes do nosso país, quer pela reprodução de monumentos, obras de arte e documentos oficiais ou históricos 
que possam interessar às repartições do Estado, estabelecimentos de ensino, arquivos, bibliotecas e museus. ${ }^{18}$

Citamos, em seguida, cinco títulos de filmes produzidos pela Secção de Fotografia e Cinema do Exército (SFCE) e que não constituem mais do que viagens de propaganda de Sidónio Pais e de promoção do seu partido, o Partido Nacional Republicano (PNR): "Colégio Militar (exercícios militares com a assistência do presidente da República)"; "Proclamação do Senhor Dr. Sidónio Pais"; "A Última Parada a que Assistiu o Presidente Sidónio Pais"; "Viagem ao Norte do Presidente Sidónio Pais"; e "Viagem Presidencial a Elvas". Ainda no plano da cinematografia, a este filmes oficiais que promovem o "Presidente-Rei", acrescem os que a nova Sociedade Lusitânia Films vai produzir, ou seja, cinco documentários de "atualidades", onde Sidónio Pais é o protagonista principal, a saber: "Tourada de Gala no Campo Pequeno"; "O Dr. Sidónio Pais no sul do país"; "Manobras no campo entricheirado de Lisboa"; "Parada Militar"; e "5 de Outubro".

\section{Homem Christo Filho e António Ferro nascem para \\ a propaganda política durante a ditadura sidonista}

E que o carisma e a imagem cesarista de Sidónio Pais funcionaram em pleno para o seu tempo e que arrastavam multidões não restam dúvidas, como se pode ver pelo testemunho do primeiro editor da revista "Orpheu”, António Ferro (1895-1956), o primeiro editor da revista "Orpheu". É bom ter presente que foi durante o mês de Novembro de 1917 que a revista "Portugal Futurista" veio a público entre nós, ou seja, a estética da vanguarda futurista é

18 SOUSA, Jorge Pais de. O Fascismo Catedrático de Salazar: Das Origens na I Guerra Mundial à Intervenção Militar na Guerra Civil de Espanha 1914-1939, p. 134. 
divulgada em vésperas da emergência da Ditadura Sidonista, bem expressa no Ultimato Futurista: Às Gerações Portuguesas do Século $X X$ de Almada Negreiros, onde este afirma - citando Marinetti - que "a guerra é a grande experiência".

Por outro lado sabemos que António Ferro nasce para a política, em plena guerra e também na sequência da experiência ditatorial Dezembrista. Na verdade, o então estudante da Faculdade de Direito da Universidade de Lisboa, foi mobilizado para Angola como oficial miliciano no início de 1918. Antes da mobilização de António Ferro ter lugar, Sidónio Pais nomeara o capitão de fragata Filomeno da Câmara (1873-1934) governador geral de Angola. Filomeno da Câmara, por sua vez, consegue a nomeação de António Ferro para seu oficial às ordens, de modo que este se torna seu colaborador pessoal e admirador político. Uma vez que, em pouco tempo, Filomeno da Câmara nomeia-o secretário geral da província de Angola e, tudo isto, numa altura em que o jovem oficial miliciano António Ferro tem vinte e três anos.

Vejamos, no entanto, o que António Ferro escreveu mais tarde sobre o "magnetismo" do presidente da República Sidónio Pais:

Foi Sidónio Pais, a figura esbelta de Sidónio, o nosso primeiro republicano sem barrete frígio, quem me arrancou a este adormecimento, a esta modorra. A primeira vez em que o vi - lembro-me bem! - encontrava-me precisamente no Martinho, no quartel general da minha indolência. Sidónio regressava do Porto. Grande multidão o aguardava diante da Estação do Rossio e suas imediações (...) Mas quando Sidónio Pais assomou à porta da estação, com o seu perfil já lendário, com aquela máscara, de traços fins mas nítidos onde se espelhava a nossa própria vontade, rodeado pelos seus ajudantes, impecáveis e juvenis nas suas fardas novas, algo de magnético se passou, algo de misterioso aconteceu - asa de anjo que me sacudiu, de anjo viril... - que me obrigou a subir 
para uma cadeira e a dar palmas, a dar vivas, freneticamente, como todos os outros (...)

E foi então que senti, pela primeira vez, a beleza, o sentido poético da palavra chefe, quando este não é um tirano; foi então que percebi o erro, a doença da minha poesia ao compreender definitivamente que as nações só se prestigiam através da grandeza da suas figuras e nunca, através da pequenez dos seus figurantes. A imagem de Sidónio Pais, "viva estátua equestre", como alguém lhe chamou, ainda me deslumbrou, me fascinou em diversas paradas e desfiles onde o seu perfil magnetizava sempre as multidões. E a ele devo esta certeza que nunca mais abandonou: A poesia das nações, a sua poesia heróica, não está nas alfurjas, nas associações secretas, ou até nos parlamentos, mas nos seus chefes ou nos seus reis, naqueles que podem ser derrubados, mortos, mas deixam as suas pátrias bem erguidas, mais altas, nos próprios pedestais donde foram apeados, violentamente, pelas paixões dos homens. ${ }^{19}$

Enquanto o jovem António Ferro se impressiona com a presença e o carisma de Sidónio Pais e a "entourage" castrense que o rodeia, e reconhece nele a figuração plena do "chefe" em política, por essa altura, Francisco Homem Christo Filho (1892-1928), um jovem e famoso jornalista radicado em Paris, viaja para Portugal. É na capital francesa que Homem Christo Filho se radicara e trabalhava como jornalista. Ali se tornara famoso no plano do jornalismo internacional. Em relação com a profissão de jornalista resolve criar a sua editora, uma livraria e a agência noticiosa FAST. Portanto, é no decurso do mês de Janeiro de 1918, e durante a viagem presidencial que o presidente da República efectua ao Norte do país, que Homem Cristo Filho aborda Sidónio Pais na cidade de Braga. O objectivo é

19 FERRO, António. D. Manuel II: O Desventurado. Lisboa: Bertrand, 1954, pp. 24-27. 
apresentar a Sidónio Pais a realização de um plano de propaganda do seu governo no estrangeiro e que consistia em criar: "uma obra de propaganda nacional, feita por todos os meios ao nosso alcance, do esforço de Portugal na guerra", a qual devia depender directamente "do Ministério a que V. Ex. ${ }^{a}$ preside" e teria como principais destinatários todos os países aliados. ${ }^{20}$

Sidónio Pais aceita o projeto e cria de imediato, no mês de janeiro de 1918, a Direcção dos Serviços de Informação e Propaganda da República Portuguesa nos Países Amigos e Aliados (DSIPRPPAA), e dá imediatamente posse ao seu diretor Homem Christo Filho. Quatro meses foram suficientes para Homem Cristo Filho, responsável pela informação e a propaganda sidonista no estrangeiro, se desvincular do partido monárquico e passar a identificar-se com a "admirável coragem moral e física do sr. dr. Sidónio Pais, a sua alta capacidade política e o seu magnífico patriotismo". ${ }^{21}$

A verdade, porém, é que a Direcção dos Serviços de Informação e Propaganda (DSIPRPPAA) não promovia em França só a imagem de Portugal no estrangeiro durante a guerra. Basta ter presente, por exemplo, que o presidente da República deposto, Bernardino Machado, que se encontrava à época exilado em Paris e ali desenvolvia uma acção política relevante no sentido de retomar a ordem constitucional de 1911, foi objecto da contra-propaganda exercida por Homem Christo Filho à frente daquele organismo governamental. Foi neste contexto de exílio político de Bernardino Machado que o director dos Serviços de Informação e Propaganda da República Portuguesa abordou, pessoalmente, os directores dos jornais de Paris para lhes enviar depois um relatório 'o mais detalhado e documentado possível, sobre o movimento de 5 de Dezembro, as suas causas

20 Citado em SOUSA, Jorge Pais de. O Fascismo Catedrático de Salazar: Das Origens na I Guerra Mundial à Intervenção Militar na Guerra Civil de Espanha 1914-1939, pp. 140-141.

21 Citado por Id., o. c., p. 141. 
remotas e as suas imediatas, as suas consequências prováveis' ${ }^{22} \mathrm{Em}$ conclusão, é criado, em plena I Guerra Mundial e por Sidónio Pais, o primeiro organismo governamental português vocacionado para fazer a propaganda de um governo ditatorial.

Com o assassinato de Sidónio Pais, a 14 de Dezembro de 1918, termina a missão de Homem Christo Filho como responsável máximo pela propaganda governamental sidonista no estrangeiro. Em 1920, e a título de homenagem póstuma ao malogrado presidente da República, Homem Cristo Filho escreve e publica, com a chancela da sua editora FAST, o livro Les Porte Flambeaux. Repare-se, contudo, que o título sugere e refere-se a todos aqueles que transportam consigo uma chama em sentido figurado, um archote, ou um facho. E, na verdade, a ilustração da capa é um desenho que representa um cavaleiro a transportar no seu braço um facho. ${ }^{23}$ Nele são biografadas diversas figuras estrangeiras que se destacaram durante a guerra, como é o caso de, entre outros, Clémenceau, Anatole France, o marechal Foch. O livro encerra com um capítulo dedicado ao único português retratado, o militar e catedrático Sidónio Pais, que abre com a seguinte citação: "La plus grande figure que la nation portugaise ait connue depuis le marquis de Pombal." 24 Escrito em tom hagiográfico, prepara com ele o caminho para a construção do mito e do culto sidonista:

La multitude ne pleurait pas seulement en lui le premier magistrat de la République, mais encore, mais surtout son bienfaiteur. L’homme universel qui avait été loyal soldat, professeur exact, mathématicien savant, à qui le Portugal devait le sens

22 Citado em SOUSA, Jorge Pais de. O Fascismo Catedrático de Salazar: Das Origens na I Guerra Mundial à Intervenção Militar na Guerra Civil de Espanha 1914-1939, p. 141.

23 Ver capa e título de CHRISTO, Francisco de Homem. Les Porte Flambeaux. Paris: Éditions FAST, [1920?].

${ }^{24}$ Id., o. c., p. 231. 
de l'organisation, l'ébauche d'une expansion panlusitanienne, d'heureuses réformes dans le domaine de l'enseignement, cet homme était l'ami des malheureux, le 'Père des pauvres...25

O jornalista Francisco Homem Christo Filho viaja, em 1923, para Itália, com a missão de entrevistar Mussolini e de escrever sobre o novo fenómeno político em afirmação que é o fascismo. Em Roma conquista a simpatia do "Duce" e resulta, ainda naquele ano, a publicação do livro apologético do fascismo Mussolini: Bâtisseur d'Avenir: Harangue aux Foules Latines. Livro que é traduzido para outras línguas e conhece enormes tiragens, tornando-se o título mais conhecido escrito e publicado por Homem Christo Filho. A edição deste livro assinala também uma nova e definitiva adesão política do seu autor ao fascismo. Em termos de história da bibliografia fascista, importa registar que uma análise da entrada "Mussolini" na Enciclopedia Italiana revela que este livro escrito por um português é pioneiro em dar a conhecer o fascismo de Mussolini em França e no mundo francófono. Na secção designada de "Principalissime opere straniere" verifica-se que é neste ano de 1923 que surgem na Europa os primeiros livros publicados sobre Mussolini. Nesse ano publica-se em língua alemã, embora no Mónaco, o livro de F. Guterbock "Mussolini und der Faschismus". E em inglês é publicado em Londres o livro de G. M. Godden "Mussolini: The Birth of the New Democracy". Por lapso, menciona-se apenas a tradução espanhola do livro de Homem Christo, "Mussolini: Arenga a la Raza Latina", que é publicada no ano de 1924 em Madrid. ${ }^{26}$ Ora, a edição original desta obra é publicada pelo autor em língua francesa, como já foi mencionado,

25 Id., o. c., p. 257.

26 Cf. "Mussolini" em Enciclopedia Italiana: Di Scienze Lettere ed Arti. Roma: Istituto della Enciclopedia Italiana, 1934, p. 162. 
no ano anterior. Trata-se de um volume de cerca de 330 páginas e muito bem informado sobre a emergência do fenómeno fascista e a afirmação política de Mussolini.

Francisco Homem Christo vai trabalhar com Mussolini em duas iniciativas importantes e que implicavam uma grande confiança pessoal e política. Primeiro, na condição de alto comissário do Congresso das Nações do Ocidente previsto e marcado para a cidade de Roma em abril de 1929, onde Mussolini estaria presente a representar a Itália fascista. Dispunha-se também a escrever uma obra, em seis volumes, intitulada L'État Fasciste. Homem Christo vem a morrer vítima de um acidente de automóvel quando conduzia em viagem de Lisboa para Roma, onde se iria encontrar com Mussolini para lhe mostrar o primeiro volume do livro que tinha em mãos. A sua morte, ocorrida com apenas 36 anos de idade, valeu-lhe a realização em Roma de um funeral com honras fúnebres de um hierarca fascista. Mais tarde, em fevereiro de 1933, Mussolini manda erigir um túmulo monumental no cemitério de Orte, para onde os seus restos mortais são trasladados em cerimónia oficial. ${ }^{27}$

\section{A constitucionalização da ditadura do Estado Novo de Salazar e a tomada de posse de António Ferro como diretor do Secretariado de Propaganda Nacional (SPN) em 1933. Afonso Costa como inimigo político, alvo de contrapropaganda e de perseguição política}

No mês de abril de 1933 entra em vigor a Constituição que define o Estado português como unitário e corporativo. Ao fim de meio ano,

27 Cf. SOUSA, Jorge Pais de. O Fascismo Catedrático de Salazar: Das Origens na I Guerra Mundial à Intervenção Militar na Guerra Civil de Espanha 1914-1939, pp. 141-142. 
e porque a propaganda é uma prioridade política, a 26 de outubro, Salazar dá posse a António Ferro como Diretor do Secretariado de Propaganda Nacional (SPN). No discurso de tomada de posse, Salazar expõe os grandes princípios da sua concepção totalitária de propaganda. Neste sentido, estabelece um corte com a lógica da chamada "guerra de Gabinetes" - que vigorara nos países que participaram na I Guerra Mundial - que elegera a propaganda como instrumento para sustentar a política intervencionista, e a guerra psicológica para a mobilização civil e militar dos portugueses na frente interna, face à declaração de guerra da Alemanha a Portugal de 9 de março de 1916.

É verdade, contudo, que a ditadura de Sidónio Pais representara um primeiro ensaio de governamentalização da propaganda, e comprova-o também a experiência de Homem Cristo Filho à frente da Direcção dos Serviços de Informação e Propaganda da República Portuguesa nos Países Amigos e Aliados (DSIPRPPAA). Vejamos, porém, quais são os dois grandes pilares em que assenta a propaganda salazarista:

[O] Secretariado não é um instrumento do Governo mas um instrumento de governo (...)

Politicamente só existe o que o público sabe que existe. ${ }^{28}$

Conclui-se, primeiro, que Salazar não concebe a ação governativa sem esta componente fundamental que é a propaganda. Segundo, num regime de censura prévia e de existência de um partido de governo que é a União Nacional, tem uma concepção totalitária da propaganda, pois só esta ocupa o espaço público da comunicação.

28 SALAZAR, Oliveira. Discursos 1928-1934. Coimbra: Coimbra Editora, 1935, pp. 258-259. 
No entanto, e mais do que saber em que consistiu a "política do espírito" que António Ferro vai desenvolver, importa-nos aprofundar as razões políticas que levaram Salazar a convidá-lo para assumir a direção da propaganda do Estado Novo. É que este era um cargo de enorme confiança política e pessoal, até porque o diretor do SPN estava sob a alçada do presidente do Conselho e com ele despachava, diretamente, todas as matérias que à propaganda governamental respeitavam, tal como as que respeitavam à União Nacional como decorria dos seus estatutos. Por outro lado, a sua nomeação ocorre numa altura em que o Estado Novo precisa da propaganda para se afirmar na ordem política interna e externa.

E será que Salazar ignorava qual fora o percurso político de António Ferro? Não. A nosso ver, as entrevistas que lhe concedeu e que foram publicadas no final de 1932, no Diário de Notícias, funcionaram como um verdadeiro exame à fidelidade política e intelectual de António Ferro. A desconfiança de Salazar está patente no processo de revisão de provas. Na verdade, e quando da publicação das entrevistas, o presidente do Conselho não abdica de rever com todo o cuidado as provas tipográficas. Ferro dá conta disto na primeira edição em livro nas "Notas de Reportagem duma Reportagem", onde reproduz em facsímile da revisão de provas feita por Salazar no texto das entrevistas com recurso ao formulário da Censura. ${ }^{29}$ Como já foi referido António Ferro iniciara a sua trajetória política, em pleno sidonismo e no quadro da sua mobilização militar para combater em Angola, onde acaba por ser escolhido para exercer o cargo de secretário do Governador, o capitão de fragata Filomeno da Câmara. E como ele escreve no livro D. Manuel II, publicado em 1954, toda a sua ação política é marcada pela ideia de "Chefe". Ideia esta que lhe é transmitida

29 Cf. FERRO, António. Salazar: O Homem e a sua Obra. Lisboa: Empresa Nacional de Publicidade, [1933], p. 177. 
sob a forma de "lição" política - para usar o seu vocabulário -, e segundo esta ordem cronológica dos "chefes" com quem aprendeu ou trabalhou diretamente: Sidónio Pais, Filomeno da Câmara e Salazar. ${ }^{30}$ A verdade é que lendo com atenção o prefácio deste livro e estudando as diferentes tentativas de golpe de estado que vão ser infligidas à República, quer durante a I Guerra Mundial, quer no período do pós-guerra, vemos que António Ferro, tal como outros sidonistas, como é o caso do alferes Jorge Botelho Moniz, se vão comprometer politicamente em vingar a morte de Sidónio Pais e, para esse efeito, derrubar a República democrática. António Ferro confirma este seu compromisso político golpista na fase em que, após a desmobilização, se torna jornalista e não regressa mais aos bancos da Faculdade de Direito da Universidade de Lisboa:

No meu regresso de Angola, indignado com a demissão de Filomeno da Câmara, com ainterrupção violenta, simplesmente política ou politiqueira, da sua acção benéfica, prometedora, alinhei francamente ao lado dos últimos defensores da memória de Sidónio Pais, chegando até a lançar-me numa perigosa actividade que tinha como objectivo principal avalorização, junto de certos intelectuais que não o conheciam suficientemente, do meu 'comandante', do antigo Governador de Angola e Timor.

Não é esta a ocasião de escrever a história desse período, entre o meu regresso de África e o meu encontro com Salazar; mas quando essa oportunidade chegar, talvez algumas pessoas, que me julgavam então um simples jornalista, um alegre amador de paradoxos, e talvez me julguem, ainda hoje, um arrivista, fiquem surpreendidas ao conhecerem a minha contribuição efectiva, real, para a criação do ambiente que nos conduziu ao 18 de Abril, re-

30 FERro, António. D. Manuel II: o Desventurado. Lisboa: Bertrand. 1954, p. 45. 
volução precursora do 28 de Maio e que teve Filomeno da Câmara como um dos principais chefes. 31

Após a desmobilização como alferes miliciano, António Ferro torna-se jornalista de uma formação partidária sidonista, ao começar por se tornar chefe de redacção de O Jornal, o órgão de imprensa do Partido Republicano Conservador, no verão de 1919. No ano seguinte trabalha também para O Século. Em 1922 faz crítica no Diário de Lisboa e passa também a dirigir a revista Ilustração Portuguesa. Neste ano publica um livro de identificação política e pessoal, que intitula Gabriele D'Annunzio e Eu. ${ }^{32}$ Este livro de entrevistas assinala a sua estreia no jornalismo internacional e vale-lhe o convite para se tornar, no ano de 1923, redator de O Diário de Noticias.

Enquanto adquire uma posição destacada e sólida no jornalismo português, António Ferro liga-se às tentativas de golpe de Estado que o Comandante Filomeno da Câmara vai liderar durante a República e a seguir na Ditadura Militar. Com efeito, e como ele escreve, "cria o ambiente" para o golpe de Estado de 18 de Abril de 1925. Note-se que existe uma descrição pormenorizada da conspiração, preparativos e manobra militar dos revoltosos sidonistas, escrita por um dos protagonistas do golpe o tenente Jorge Botelho Moniz. 33 Contribui para o movimento do 28 de Maio de 1926 que derruba a I República e, posteriormente, uma vez instaurada a Ditadura Militar conspira dentro de uma das facções militares para que, uma vez mais, Filomeno da Câmara aceda ao poder. Neste sentido, envolve-se no chamado golpe dos "Fifis". Mais uma

31 FERro, António. D. Manuel II, pp. 33-34.

32 FERRO, António. Gabriele D’Annunzio e Eu. Lisboa: Portugália, 1922.

33 MONIZ, Jorge Botelho. O 18 de Abril: Elementos para a História d'uma Revolução Vencida. Lisboa: Ed. de Autor, 1925. 
tentativa de golpe que ocorre a 12 de Agosto de 1927, comandada pelo capitão de fragata Filomeno da Câmara com o apoio político de Fidelino de Figueiredo.

É claro que quando António Ferro procura Salazar para o entrevistar, no final de 1932, o presidente do Governo conhece a trajetória jornalística e a militância política sidonista de António Ferro. Cauteloso, em termos políticos, no que respeita a qualquer conspirador, Salazar desconfia do jornalista. Conhece, no entanto, os livros de entrevistas a golpistas e a ditadores que tornaram António Ferro famoso no mundo da reportagem jornalística internacional em Portugal, como é o caso de Gabriele D'Annunzio e Eu e Viagem à Volta das Ditaduras. Este último livro data de 1927 e nele António Ferro, nas entrevistas que faz a Mussolini, declara-se fascista e seu admirador pessoal. Julgamos que nestes seus livros e depois na preparação do livro de entrevistas Salazar. O Homem e a sua Obra, Ferro tem bem presente e subjacente o modelo de livro de propaganda de reportagem que o seu mentor Homem Cristo Filho - nos campos jornalístico, da propaganda e político, ambos passam pela experiência de ditadura do sidonismo em direção ao fascismo - publicara em Paris, logo no ano de 1923, com o título de Mussolini: Batisseur d'Avenir. A realização, revisão e publicação das entrevistas no Diário de Notícias, em dezembro de 1932, representa um exame decisivo à fidelidade política de António Ferro.

Em resultado, Salazar decide publicar em livro as entrevistas que concedera, e para esse efeito escreve o prefácio, com data de 16 de janeiro de 1933, de Salazar: O Homem e a sua Obra. ${ }^{34}$ Este deve ser o livro de propaganda que em Portugal é mais conhecido. A primeira edição, por exemplo, teve também uma tiragem especial de 125 exemplares. Lançada esta fabulosa operação de propaganda no início do ano de 1933, em abril entra em vigor a Constituição

${ }^{34}$ Cf. FERRO, António. Salazar: O Homem e a sua Obra, p. XLI. 
corporativista de 1933 e em outubro Salazar está a dar posse, como já foi dito, a António Ferro, como diretor do SPN. E quem é que Ferro vai convidar, por exemplo, para trabalhar na máquina de propaganda do Estado Novo no campo do cinema? Alguns dos antigos estudantes de Belas Artes, e que nessa qualidade haviam publicado, em 1917, a revista "Sphinx: Revista de Novos", ou seja, os agora arquitectos e realizadores de cinema Cottinelli Telmo (1897-1948) e Leitão de Barros (1896-1967). Vimos que estes estiveram ligados, durante a ditadura sidonista, à criação da Sociedade Lusitânia Films. Esta começou por produzir os já elencados filmes de propaganda sidonista. Sociedade Lusitânia que proporcionou, em 1918, a Leitão de Barros realizar o seu primeiro filme de ficção "Mal de Espanha" e o documentário de propaganda "Sidónio Pais: Proclamação do Presidente da República". Estes dois arquitectos e realizadores de cinema retomam no final da Ditadura Militar esta experiência no campo da produção e distribuição de filmes com a criação, em junho de 1932, da Tobis Portuguesa, onde António Ferro também é um dos accionistas fundadores. Como é sabido todo o catálogo de filmes que integra a denominada "comédia portuguesa" é produzido e realizado, em grande medida, nos estúdios da Tobis. ${ }^{35}$ Inaugura este género a produção, em 1933, de "A Canção de Lisboa", realizado por Cottinelli Telmo. Enquanto Leitão de Barros realiza "As Pupilas do Senhor Reitor" no ano de 1935. O mesmo Leitão de Barros realiza, enquanto decorre a Guerra Civil de Espanha e em consequência o processo de fascização do Estado Novo tende a profundar-se na ordem interna, os filmes de propaganda sobre as milícias: "Legião Portuguesa" e "Mocidade Portuguesa", ambos de 1937. O mesmo Leitão de Barros concebe, ao serviço do SPN e a partir de 1934,

35 Cf. sobre os chamados "filmes cómicos" TORGAL, Luís Reis (coord.) - O Cinema sob o olhar de Salazar. Lisboa. Círculo de Leitores, 2000, pp. 24-26. 
a coreografia e as letras das músicas das "marchas populares" das Festas da Cidade de Lisboa.

\section{Afonso Costa como inimigo político, alvo de contrapropaganda e de perseguição política}

Abordemos, agora, o problema da contrapropaganda. Na medida em que, nem sempre temos presente as consequências que dela resultam para os visados, em termos de longo prazo, por exemplo, ao nível da própria elaboração da história. A verdade é que tendemos a ver apenas os efeitos imediatos da contrapropaganda, ou seja, como a propaganda que visa a anulação dos efeitos daquela que se the opõe. A nosso ver, porém, a "eficácia" da máquina de propaganda salazarista influiu, e muito, naquele que pode ser considerado o segundo "recalcamento" infligido na representação histórica e política de Afonso Costa (1871-1937) em relação ao lugar que ocupa na história do século XX português.

A publicação, em Lisboa, no início do ano de 1933 de Salazar: O Homem e a sua Obra é uma forma de apresentar à opinião pública portuguesa, através da forma de entrevista, Salazar e o seu pensamento político. Este surge em oposição à Constituição de 1911 e ao sistema demoliberal republicano e, em particular, à governação e ao socialismo reformista de Afonso Costa. Tudo numa altura em que Salazar é já presidente do Ministério, em acumulação com a pasta das Finanças, e prepara a Constituição de 1933 para construir a saída política para a Ditadura Militar instaurada a 28 de maio de 1926, e tornar este movimento militar, o ano I da Revolução Nacional, percursor do Estado Novo corporativo. Vejamos, porém, como Afonso Costa e as ideias que defende do socialismo integral são particularmente visadas por Salazar, sem que este último refira o seu nome. Na verdade, é na segunda entrevista feita por António Ferro, e que é designada de 
"Na Fronteira das Ideias", que Salazar se demarca ideologicamente do comunismo, e, em seguida, expressamente, do socialismo de Afonso Costa. ${ }^{36} \mathrm{Na}$ nossa interpretação, é aqui que se percebe que o pensamento e a ação política de Afonso Costa funcionam, historicamente, como o contraponto democrático do fascismo catedrático de Salazar. Este é delineado por Salazar na entrevista seguinte "III - A Ditadura e o seu contacto com a Nação", procurando situá-lo na família política fascista, mas identificando as suas diferenças em relação ao fascismo de Mussolini. ${ }^{37}$ Enquanto na primeira entrevista o Ditador das Finanças é apresentado e posicionado no quadro ditatorial das diferentes forças políticas em conflito no que resta da cena partidária portuguesa. Vejamos, todavia, a pergunta que o jornalista sidonista António Ferro faz e que qualifica de um "dos capítulos mais empolgantes deste inquérito", e que neste livro de entrevistas o "capítulo" vem claramente identificado de "Socialismo integral":

Não concorda, pois, com a aplicação do "socialismo integral" no nosso País?

O dr. Salazar, que não gosta tanto de jogar ao sisudo, como se diz, tem um sorriso largo que já é riso e responde-me sem azedume, sem combatividade, como quem faz esgrima para se entreter:

Fórmula cediça que não nos traz nada de novo. É talvez possível encontrá-la numa tese interessante, velha de quarenta anos, assinada por um ilustre jurisconsulto português, e em que o seu autor pretendia responder, na audácia legítima da sua mocidade, a uma célebre encíclica de Sua Santidade o Papa Leão XIII. Sei que esse talentoso advogado, que foi um vulto da política portuguesa do passado, continua a defender e a aplicar as ideias da

36 Cf. FERRO, António. Salazar: O Homem e a sua Obra, pp. 59-66.

37 Cf. Id., o. c., pp. 73-96. 
sua tese como se elas tivessem acabado de nascer no seu espírito. Admirável constância... Mas o mundo tem andado... 38

Não restam quaisquer dúvidas, com esta pergunta de Ferro e a resposta de Salazar, sobre quem e que doutrinas são visadas nela: Afonso Costa e as suas ideias socialistas integrais expostas na sua tese de doutoramento e defendidas ao longo de toda sua ação política. Repare-se, todavia, como Salazar não identifica e tão pouco se refere ao nome do autor e professor catedrático da tese A Igreja e a Questão Social que fora defendida, em 1895, na mesma Faculdade de Direito da Universidade de Coimbra, onde ele também é professor. ${ }^{39}$ Importa ter presente que Afonso Costa fora demitido, pelo Decreto de 12 de março de 1927, do cargo de professor catedrático da Faculdade de Direito da Universidade Lisboa (FDUL). Demissão que foi imposta sem a instauração prévia de qualquer processo disciplinar. ${ }^{40}$ Esta terá sido, talvez, a consequência direta, moral e financeira, mais visível para Afonso Costa, que vivia e exercia advocacia em Paris, em resultado do fracasso e da repressão que se seguiu à revolta republicana, de 3 a 9 de fevereiro de 1927, que eclodiu no Porto e que alastrou a Lisboa. Originou, todavia, um conjunto de revoltas constitucionais, militares e civis, também conhecidas como o fenómeno republicano do "Reviralhismo". Os exilados políticos que dela resultaram, e que se vão acolher na Galiza, fundam a Liga de Defesa da República, mais conhecida por Liga de Paris, onde Afonso Costa passa a ter um papel primordial. Não é portanto por acaso que, neste final de ano de 1932, Salazar se refere apenas a

38 FERRO, António. Salazar: O Homem e a sua Obra, pp. 56-60.

39 Cf. COSTA, Afonso. A Igreja e a Questão: Analyse Critica da Encyclica Pontificia De Conditione Opifium, de 15 de Maio de 1891. Coimbra. Imprensa da Universidade, 1895.

40 Cf. CAETANO, Marcello. Apontamentos para a História da Faculdade de Direito de Lisboa. Lisboa: Separata da Revista da Faculdade de Direito da Universidade de Lisboa, vol. XIII, 1961, p. 86. 
Afonso Costa como sendo "um ilustre jurisconsulto português", ou um "talentoso advogado" e, por último, como alguém que "foi um vulto da política portuguesa do passado". É que estava injustamente impedido, pela Ditadura Militar, de ser professor universitário na Faculdade de Direito da Universidade de Lisboa, pelo que tem de viver no exílio, em Paris, do seu trabalho como advogado.

Conclui-se, porém, que Salazar é conhecedor do pensamento político e jurídico de Afonso Costa. E, em concreto, da sua tese de doutoramento, pois relaciona-a de imediato com a defesa e a aplicação, em Portugal, das ideias do socialismo integral de Benoît Malon (1841-1893). A título de exemplo, e a propósito de o autor de A Igreja e a Questão Social se mostrar nela favorável à socialização de determinados serviços e meios de produção, e dos transportes coletivos em concreto, veja-se como Salazar se demarca, ideologicamente, nesta matéria:

Continuando no capítulo do socialismo, concorda o sr. Presidente com a socialização de certos serviços e de certos meios de produção, como a socialização dos transportes por exemplo? ...Sou absolutamente hostil a todo o desenvolvimento de actividade económica do Estado em todos os domínios em que não esteja demonstrada a insuficiência dos particulares. ${ }^{41}$

Portanto, Afonso Costa e o seu pensamento político socialista, bem como a sua governação, são diretamente visados por Salazar nas entrevistas que concede, no final de 1932, ao jornalista sidonista António Ferro. É por isso que, em Paris, Afonso Costa, que vinha recusando dar entrevistas sobre Portugal, no caso do jornalista José Jobim pelo menos há três anos, resolve responder no exílio a

${ }^{41}$ FERRO, António. Salazar: O Homem e a sua Obra, pp. 64 e 65-66. 
Salazar. ${ }^{42} \mathrm{O}$ antigo presidente da Assembleia Geral da Sociedade das Nações começa por expor as reservas que tem, assentes em razões patrióticas, em conceder entrevistas a jornalistas estrangeiros sobre a situação política portuguesa:

Uma entrevista? Diz-me. Pois, seja! Mas quero que note em que condições especiais e excepcionais tha vou dar. Tenho sempre hesitações e melindre em contar a estrangeiros o que se passa de desagradável e de injusto no meu país: o meu orgulho pessoal e de português não me permite solicitar apoio ou solidariedade a estranhos e muito menos fazer-lhe queixas. Conto demais comigo e com a força dos princípios democráticos que sempre tenho servido, para me julgar precisado de socorro alheio. ${ }^{43}$

Não obstante estas reservas iniciais colocadas por Afonso Costa, José Jobim é muito claro e considera que este lhe concedera "a sua entrevista mais sensacional", o mesmo jornalista que inicia este texto introdutório demarcando-se do seu entrevistado, com a seguinte primeira frase: "Não sou amigo nem partidário do Sr. Afonso Costa." ${ }^{44} \mathrm{E}$ percebemos a esta distância temporal, em termos de debate histórico e político, melhor a razão de ser desta afirmação do jornalista brasileiro. Não é por acaso que ele escreve que este seu livro de entrevistas, que é publicado no Rio de Janeiro em maio de 1934, "é uma resposta ao 'Salazar' do Sr. António Ferro." 45 Para todos os efeitos são também dois professores universitários que

42 JOBIM, José. A Verdade sobre Salazar: Entrevistas concedidas em Paris pelo Sr. Affonso Costa, ex-presidente da Liga das Nações e antigo primeiro-ministro de Portugal. Rio de Janeiro: Calvino Filho, 1934, p. 7.

43 Id., o. c., p. 20.

44 Id., o. c., p. 7.

45 Id., Ibidem. 
debatem a tese de doutoramento de Afonso Costa e, precisamente, o desempenho de Salazar como ministro das Finanças.

Existe, no entanto, uma motivação urgente que fazia o antigo presidente do Governo e ministro das Finanças Afonso Costa aceitar a entrevista de José Jobim e que se prende com o fato de, na sua análise económica e financeira, o "orçamento do Doutor Salazar para 1933-1934" estar "manifestamente em deficit apesar das afirmações em contrário do ditador." ${ }^{\not 6}$ Não vamos entrar nesta discussão técnica, todavia, ao consultar a obra coordenada pelo especialista em história da economia Nuno Valério Os Orçamentos no Parlamento Português, verifica-se que o orçamento de 1933-1934 foi efetivamente deficitário. E, portanto, quem tinha razão, nesta matéria concreta, foi Afonso Costa e não Salazar. ${ }^{47} \mathrm{Na}$ verdade, importa recordar que Afonso Costa torna-se cedo um especialista em matéria de Finanças Públicas. Recorde-se que os dois primeiros anos de docência na Faculdade de Direito da Universidade de Coimbra (1896-97 e 1897-98) são dedicados a lecionar e a publicar estudos de Economia Política. E logo que, pela primeira vez, preside ao Governo em acumulação com a pasta das Finanças, obtém, em 1913-14, os dois superavites de 1912-13 e 1913-14. Os primeiros que um ministro das Finanças obtém ao fim de mais de 50 anos de exercícios orçamentais. E, para este efeito, promulgou, entre outros diplomas, na área das finanças públicas, a famosa Lei "Travão" de março de 1913. E fruto da sua experiência política como ministro das Finanças e dos seus conhecimentos como professor universitário de Economia Política, Afonso Costa cria e é titular da cadeira de "Direito Financial - Orçamentologia" , no

46 JOBIM, José. A Verdade sobre Salazar: Entrevistas concedidas em Paris pelo Sr. Affonso Costa, ex-presidente da Liga das Nações e antigo primeiro-ministro de Portugal, p. 22.

47 Cf. VAlÉRIO, Nuno (coord.) et al. Os Orçamentos no Parlamento Português. Lisboa: Assembleia da República; Dom Quixote, 2006. ISBN 972-20-2911-8, p. 258. 
Instituto Superior de Comércio de Lisboa, esta é regida interinamente por José Eugénio Dias Ferreira. ${ }^{48}$

Em relação ao debate político e à concepção de organização do Estado e da sociedade, Afonso Costa vai responder à crítica de Salazar às suas ideias socialistas. Na verdade, e quando é questionado sobre a questão social, afirma:

Foi uma questão que sempre me interessou. Estudante, dediquei-lhe a minha tese de doutoramento.

E num contexto de política internacional em que em 1935 se iriam constituir, em Espanha e França, os governos de Frente Popular, e no combate que trava no exílio de Paris no sentido de voltar ao regime constitucional de 1911, considera que é fundamental acautelar os direitos dos trabalhadores. É que a questão social, não é apenas um problema que o ocupou na sua juventude e na sua tese de doutoramento, mas trata-se de uma preocupação presente em toda a sua vida política. E que na sua perspetiva de socialista reformista ela só pode ser resolvida, através da realização de reformas no mundo do trabalho. Recorde-se que se deve ao primeiro governo da União Sagrada que Afonso Costa integrou como ministro das Finanças, em pleno decurso da I Guerra Mundial, a criação, em março de 1916, do Ministério do Trabalho e da Previdência Social. Aliás, fora também no primeiro governo que Afonso Costa presidiu, em 1913 e 1914, que é criado o Ministério da Instrução Pública. A criação dos ministérios da Instrução, e do Trabalho, está prevista no programa do PRP/Partido Democrático, de 1912, que liderou, e não no programa do Partido Evolucionista de António José de Almeida. ${ }^{49}$

48 Cf. da $23 .^{\text {a }}$ cadeira em INSTITUTO SUPERIOR DE COMÉRCIO. Anuário 1913-14 a 1916-17. Lisboa: Tipgrafia A Editora L.da, 1917, pp. 249-250.

49 Cf. LEAL, Ernesto Castro. Partidos e Programas. Coimbra: Imprensa da Universidade, 2008, pp. 151 e 155. 
A República tem de procurar garantir o direito ao trabalho que tenha origem num contrato livremente estabelecido. Não podemos alheiar-nos das condições em que vive a nossa classe trabalhadora. São deploráveis. A República, para ser fiel à sua origem popular e à função que necessariamente lhe compete, tem de cuidar - mas a sério, resolutamente - de melhorar progressivamente o nível de vida, quer material, quer espiritual da nossa classe operária. Para isso teremos de estabelecer de uma maneira eficaz e insofismável melhores condições de execução do trabalho, assegurando e garantindo os trabalhadores e suas famílias contra a doença, a invalidez, a velhice e o desemprego e em certos casos de morte, além dos causados por acidentes de trabalho. 50

Afonso Costa vai mais longe e preconiza a "inscrição de um artigo novo” na Constituição da República de 1911, no sentido de consagrar o direito ao trabalho e à sua proteção pelo Estado. Por outro lado, esta reforma constitucional deve também consagrar o princípio da cogestão nas empresas, ou seja, os trabalhadores devem não só participar na administração das empresas, mas também beneficiarem dos seus lucros. A redação deste novo artigo deve começar assim:

O trabalho é uma obrigação social e goza de proteção do Estado e das leis nos termos seguintes: (enumeração daqueles preceitos e da participação dos trabalhadores na administração das respectivas empresas e nos seus benefícios líquidos). 51

50 JOBIM, José. A Verdade sobre Salazar: Entrevistas concedidas em Paris pelo Sr. Affonso Costa, ex-presidente da Liga das Nações e antigo primeiro-ministro de Portugal, p. 117.

51 JOBIM, José. A Verdade sobre Salazar: Entrevistas concedidas em Paris pelo Sr. Affonso Costa, ex-presidente da Liga das Nações e antigo primeiro-ministro de Portugal, p. 118. 
As entrevistas que Afonso Costa concede, no exílio de França, ao jornalista brasileiro José Jobim e que este publica com o título A Verdade sobre Salazar, constituem, por sua vez, uma resposta política à crítica que Salazar lhe fizera no livro de propaganda Salazar: O Homem e a sua Obra (1933), e têm, apesar da censura, um impacto político em Portugal. Na verdade, o livro circula em Portugal numa altura em que no final do mês de maio, de 26 a 28, decorreu, na Sociedade de Geografia, o I Congresso da União Nacional. Na sequência do I Congresso da UN, as entrevistas do antigo presidente do Governo e ministro das Finanças Afonso Costa colocam em causa e questionam a autoridade da política financeira de Salazar. E levam este a convocar e reunir, expressamente, a 11 de julho de 1934, o conselho de Ministros. Na sequência, Salazar resolve escrever uma Nota Oficiosa "ad hominem" e que é publicada, a 17 de julho de 1934, em todos os jornais diários portugueses..$^{52}$ O título que Salazar escolheu para esta sua Nota Oficiosa é o seguinte: "I - Duas Escolas Políticas". Na verdade, sabendo nós a sequência cronológica das entrevistas concedidas por Salazar e depois a resposta de Afonso Costa, enquanto professores universitários, chefes de governo e ministros das Finanças, percebe-se bem a razão da escolha por Salazar deste título para iniciar o texto desta sua Nota Oficiosa "ad hominem". A intolerância de Salazar, em relação às críticas de Afonso Costa no que respeita ao orçamento geral do Estado para 1933-9134 - e que se veio a verificar, posteriormente, que foi efetivamente deficitário como Afonso Costa anteviu -, tal como a reafirmação das suas ideias políticas como socialista reformista no exílio de França, enquanto chefe da oposição ao Estado Novo de Salazar, as quais deviam ser consagradas na Constituição da República de 1911, levam Salazar a declará-lo nela, expressamente, como seu "inimigo político". Esta

52 Cf. NOGUEIRA, Franco. Salazar: Os Tempos Áureos (1928-1936). Coimbra: Atlântida Editora, 1977, vol. II, p. 277. 
Nota Oficiosa, por sua vez, desencadeia uma poderosa operação de contrapropaganda pelo SPN de António Ferro e, paralelamente, inicia um processo de perseguição política contra Afonso Costa, cujos efeitos vão influenciar, em grande medida, a historiografia sobre a I República. Vejamos, então, em que termos Salazar radicaliza e põe fim ao confronto político ao considerar-se irredutível nas suas posições:

Tem-me acontecido a mim ter de me referir à obra do sr. dr. Afonso Costa e ao equilíbrio das contas em 12-13 e em 13-14, que se lhe não deve só a ele mas ao engenheiro Vicente Ferreira. Nas minhas lições de Coimbra, no relatório do meu primeiro orçamento para 28-29, na entrevista publicada em O Século em 13 de Dezembro de 1928 sobre a situação cambial, na Exposição- documentário do Parque Eduardo VII, para a qual os números relativos de finanças públicas foram preparados desde 1910, reconheci sempre os factos favoráveis daquelas administrações, e não só reconheci como me regozijei com eles - portuguesmente. Estou dentro dos meus princípios, como o inimigo, negando cegamente a obra da Ditadura, está dentro dos seus. Duas escolas políticas irredutíveis: discussões para quê? 53

Em relação à operação de contrapropaganda que a Nota Oficiosa "I - Duas Escolas Políticas" de Salazar desencadeia citamos dois exemplos, enquanto em matéria de perseguição política analisaremos um caso concreto.

Quanto à contrapropaganda são publicados, em 1935, dois livros contra Afonso Costa. Um primeiro que resulta de vários artigos publicados na imprensa, os quais são depois reunidos em livro com o

53 SAlAZAR, António de Oliveira. "I - Duas Escolas Políticas", em GUIMARÃES, Alberto. A Verdade sobre Afonso Costa. Lisboa: Edição de Autor, 1935, p. 222. 
título "Esta é a verdade sobre Afonso Costa". O seu autor é Henrique Cabrita, que é membro da Comissão Executiva da União Nacional. Para este efeito, e como nos informa o biógrafo de Salazar, Henrique Cabrita foi várias vezes recebido por Salazar para este lhe dar as indicações necessárias para escrever os artigos na imprensa. ${ }^{54}$ Este último facto confirma que Salazar conhecia muito bem a trajetória de Afonso Costa, no plano universitário, do exercício da advocacia e, claro está, no domínio da ação política. O outro livro que vem a público, neste mesmo ano, já foi citado e é da autoria do monárquico Alberto Guimarães. Intitula-se $A$ Verdade sobre Afonso Costa e reproduz na íntegra a Nota Oficiosa de Salazar, lança nele fortes ataques políticos e coloca também em causa a honorabilidade pessoal de Afonso Costa como advogado. Este deixou de ser, nas palavras de Salazar a António Ferro do final de 1932, o "ilustre jurisconsulto português" e um "talentoso advogado", para passar a ser um torpe advogado. Nas palavras iniciais do autor, Afonso Costa é anatematizado e há-se ser julgado pelo "tribunal" da história que o verá como o "homem sinistro sobre quem a História há-de debruçar-se, serena e justa, para the analisar os actos e apurar as tremendas responsabilidades que the cabem na desmoralização e ruína a que chegou, sob a sua influência esta pobre nacionalidade." $55 \mathrm{O}$ ano de 1935 é também o ano em que as associações secretas, como o Grande Oriente Lusitano, são extintas. ${ }^{56}$

54 Cf. NOGUEIRA, Franco. Salazar: Os Tempos Áureos (1928-1936), vol. II, p. 278.

55 GUIMARÃES, Alberto. A Verdade sobre Afonso Costa, p. 9. A propósito da construção das representações historiográficas sobre Afonso Costa, registe-se que, após o 25 de abril de 1974, esta Nota Oficiosa "I - Duas Escolas Políticas" de Salazar vem a ser publicada de novo e na íntegra por CAMPOSA, Carlos. Respondendo a Afonso Costa: com um preâmbulo e comentário sobre o 25 de Abril. Barcelos: Ed. de Autor, 1976, pp. 15-31.

56 Cf. Lei n. ${ }^{\circ} 1$ 901, em MARQUES, A. H. Oliveira. A Maçonaria Portuguesa e o Estado Novo.3. ${ }^{a}$ ed. Publicações Dom Quixote, 1995, pp. 345-347. 
Em maio de 1935, Afonso Costa (Filho) requer, nos termos da lei, juntamente com o licenciado Francisco Maia de Loureiro, a prestação de provas para doutoramento em Ciências Político-Económicas na Faculdade de Direito da Universidade de Lisboa (FDUL). No mês de novembro, o Conselho Escolar admitiu a concurso a sua dissertação Parlamentarismo, Dissolução, Referendum. ${ }^{57}$ Acontece que este filho de Afonso Costa doutorara-se em Direito em 1928, pela Universidade de Paris (Sorbonne), onde apresentara e defendera a tese Des Indemnités dues par l'Allemagne en vertu du traité de Versailles, pour dommages causeés anteérieurment à l'ouverture des hostilités $^{58}$. Registe-se que quando Afonso Costa (Filho) apresenta o requerimento para prestar provas de doutoramento na Faculdade Direito de Lisboa está em marcha a operação de contrapropaganda contra o seu pai, desencadeada, no verão de 1934, com a publicação da Nota Oficiosa "I - Duas Escolas Políticas" de Salazar. No dia 8 de janeiro de 1936, Afonso Costa Filho "concluiu as provas, tendo sido excluído por unanimidade", segundo escreve Marcello Caetano.59 Como se explica que alguém que é doutorado pela Sorbonne seja "excluído por unanimidade", pelo júri de professores da Faculdade de Direito da Universidade de Lisboa? Uma vez que a tese está publicada só razões de conjuntura política e as convicções democráticas expressas nela pelo seu autor podem explicar um resultado negativo unânime. Vamos só referir três argumentos. Primeiro, a tese começa por ser dedicada ao "meu querido Pai: professor, parlamen-

\footnotetext{
57 Esta tese acabara de ser impressa no dia 7 de maio, cf. COSTA (FILHO), Afonso Parlamentarismo, Dissolução, Referendum. Lisboa: Tipografia Couto Martins, 1935.

58 Cf. COSTA (FILHO), Afonso. Des Indemnités dues par l'Allemagne en vertu du traité de Versailles, pour dommages causeés anteérieurment à l'ouverture des hostilités. Paris: PUF, 1928.

59 CAETANO, Marcello. Apontamentos para a História da Faculdade de Direito de Lisboa. Lisboa: Separata da Revista da Faculdade de Direito da Universidade de Lisboa, vol. XIII, p. 127.
} 
tar e grande democrata."60 É possível que esta dedicatória tenha funcionado, nesta conjuntura histórica, política e jurídica concreta, como uma espécie de provocação para o júri. Segundo, e a concluir a Introdução da tese, o autor afirma que procurará sempre que possível colocar-se "num campo objectivo. Apesar disso, não podemos nem queremos negar que as nossas simpatias intelectuais e morais vão para o regime parlamentar verdadeiramente democrático, que nos parece ser a melhor de todas as formas de Governo." ${ }^{61}$ Terceiro, nas conclusões da tese, Afonso Costa (Filho) escreve: "Democracia e Parlamentarismo, eis as fórmulas de salvação politica, tais quais as indica e defende a ciência e as sanciona e enaltece a prática seguida, desde há muito, nos países que podem dar lições de conduta política a toda a Europa: a Inglaterra e a França."62 Esta é uma crítica objetiva à Constituição corporativista de 1933 que então estava em fase de afirmação política e jurídica. A concluir esta "exclusão por unanimidade" do candidato Afonso Costa (Filho), já Doutor pela Universidade de Paris, impossibilitou que as suas habilitações fossem reconhecidas e, por conseguinte, nunca conseguiu, por exemplo, exercer advocacia em Portugal e muito menos ser professor universitário. Por isso, teve de ser sempre, ao longo da sua vida, um comerciante.

É claro que este foi um rude golpe desferido no exilado Afonso Costa. Tudo num ano em que este lidera a Frente Popular Portuguesa em Paris, quando eclode a 18 de julho, a Guerra Civil de Espanha. e até falecer subitamente em 1937. Afonso Costa estava indigitado para ser Grão-mestre do Grande Oriente Lusitano quando vem a falecer, subitamente, em Paris, a 11 de maio de 1937.

\footnotetext{
${ }^{60}$ Cf. COSTA (FILHO), Afonso. Parlamentarismo, Dissolução, Referendum, p. (V).

61 Id., o. c., p. XI.

62 Id., o. c., p. 421.
} 


\section{Conclusão}

A Grande Guerra foi a primeira guerra total, no sentido em que a propaganda do esforço de guerra foi desde o início mais uma das armas "modernas" para manter a população e os combatentes motivados para a manutenção do esforço de guerra ao longo de mais de quatro anos de duração do conflito mundial. Portugal não constituiu excepção a esta realidade, atente-se à constituição do gabinete que o ministro da Guerra Norton de Matos organizou, o qual incluía dois colaboradores civis responsáveis, oficialmente: pela pintura e pelo desenho, Sousa Lopes; e pela fotografia, António Garcez. Também criou duas estruturas militares vocacionadas para a propaganda pela imagem dentro do Exército, a saber: a Secção de Fotografia do CEP; e a Secção Cinematográfica do Exército (1917).

É na sequência do golpe de Estado sidonista que derrubou o segundo governo da União Sagrada, presidido por Afonso Costa, que Sidónio procedeu à suspensão da Constituição de 1911, dissolve o parlamento, exila o presidente da República Bernardino Machado e manda prender o presidente do Governo sem lhe instaurar qualquer processo. Procede à fusão daquelas duas secções do Exército para concentrar num só organismo, a Secção Fotográfica e Cinematográfica do Exército, a propaganda pela imagem fixa e em movimento, mas agora para a colocar ao serviço da construção da sua imagem política. Por outro lado, cabe também a Sidónio Pais criar, em Janeiro de 1918, o primeiro organismo governamental vocacionado para a propaganda, a Direcção dos Serviços de Informação e Propaganda da República Portuguesa nos Países Amigos e Aliados (DSIPRPPAA), nomeando para seu director Francisco Homem Cristo Filho, dentro em breve um dos mais destacados fascistas, no plano internacional, do início da década de 1920. Portanto, a ditadura de Sidónio Pais, instaurada em pleno decurso da I Guerra Mundial, foi pioneira e soube apropriar-se deste instrumento da máquina de guerra, mo- 
derna e total, que foi a propaganda, para a colocar ao serviço do seu projecto político pessoal e ditatorial.

Abordámos, ainda, a cumplicidade política, sidonista e golpista, em que surgem para a propaganda em Portugal os pioneiros Homem Cristo Filho e António Ferro. Ambos são autores de dois livros que constituem marcos na promoção do jornalismo ditatorial, respetivamente: Mussolini: Batisseur d'Avenir (1923) e Salazar: O Homem e a sua Obra (1933). A análise destes dois livros revela, a nosso ver, a identidade e as diferentes tendências dentro da lógica política do pensamento fascista.

Vimos, por último, como Afonso Costa se torna o "inimigo" político de Salazar, em julho de 1934, depois de ter sido afastado do poder pela ditadura de Sidónio Pais a 5 de Dezembro de 1917 e, em resultado, ter conhecido o seu primeiro exílio em Paris. Em consequência, e na lógica política de contrapropaganda desencadeada pelo SPN dirigido por António Ferro, surge a perseguição política enquanto antigo professor universitário, político e estadista destacado.

É que Afonso Costa lidera no exílio e até falecer em Paris, entre 1936 e 1937, a Frente Popular Portuguesa de oposição ao Estado Novo de Salazar, em coerência com o seu ideário socialista reformista de toda uma vida política. 